\title{
The Role of Administrator and Procedure of Payment Suspension in the Commercial Court:
}

\author{
A Case Study
}

\author{
I Made Arjaya \\ Faculty of Law \\ Universitas Warmadewa \\ Denpasar, Indonesia \\ md.arjaya@gmail.com
}

\begin{abstract}
The purpose of the research is to examine the authority of administrator and the procedures of Suspension of Payment Obligations (PKPU) of PT. RR and JCT at Surabaya Commercial Court. This type of research is normative law research with statute approach, conceptual approach and cases approach. The legal substances used in this study are primary legal materials and secondary legal materials. The resources of legal material obtained from case studies. The legal sources were collected literature studies and case analysis. The analysis used in this research is descriptive analysis that is by describing the results of research that has been collected and analyzed. The result indicate that the administrators have authority to announced court statement, organizing meetings, receive registration, prepare the creditor bill list, preparing settlement plan, prepare a voting list and make a report. The procedures of suspension of payment begins with an application filed by a debtor or creditor. The application must be granted by the court by issuing a statement for 45 days and can be extended up to 270 days.
\end{abstract}

Keywords-bankruptcy; suspension of payment; receiver and administrator

\section{INTRODUCTION}

PT. Bank UOB Indonesia, a limited liability company incorporated under the Law of the Republic of Indonesia in Jakarta, having its office address at UOB plaza, MH. Thamrin Street 10th central Jakarta 10230, as the applicant has submitted an application letter dated February 13th, 2017 received at the Commercial Court Clerk at the Surabaya district court on February 13th, 2017, register number: 4/Pdt.SusPKPU/2017/PN. Niaga Sby. The applicant has provided credit facilities to PT. RR, a limited liability company incorporated under Indonesian law domiciled in Bali, having its address at Arjuna street number 1 Legian Village, Kuta Sub-district, Badung Regency, Bali, as Respondent I. To guarantee the repayment of the debt of Respondent I, JCT, Indonesian citizen having address at Pasir Putih Street V/19, RT.008/RW.010, Ancol Sub-District, Pademangan Sub-District, North Jakarta, as respondent II, has provided personal guarantee to the applicant [1].
The petitioner has repeatedly warned the respondent I and the respondent II, but remains negligent in fulfilling its obligations. In addition to having a loan to the Petitioner, Respondent I and Respondent II also have debt to other creditors, PT. Caturbangun Mandiriperkasa. The petitioner estimates it has even been proven that the respondent I and the respondent II cannot continue to repay the debts that have fallen over time and can be billed, and appealed to the respondent I and the respondent II (debtor) to suspension of payment, appoint the supervising judge and appoint I Made Arjaya and $\mathrm{Ni}$ Wayan Umi Martina as the team of administrators.

After the panel of judges summons the parties, examining the evidence and witnesses, then on Monday, March 20th, 2017 has been decided in a court hearing open to the public by the judge, stating the respondent I and respondent II under suspension of payment while for 45 days from the date the declare is pronounced.

Based on the background of the above problems then in this research proposed the legal issues (LI) as follows:

LI1: What is the authority of administrator in suspension of payment PT. RR and JCT at the commercial court at the Surabaya district court?

LI2: How is the procedure of suspension of payment?

\section{METHOD}

This type of research is normative law research with statute approach [2], conceptual approach and cases approach. The legal substances used in this study are primary legal materials and secondary legal materials. Legal materials are obtained from case studies. The legal sources were collected through literature studies and case analysis [3]. The technique of collecting legal materials used in this study is to use a card consisting of a quote card, summary card, and a review card. The analysis used in this research is descriptive analysis that is by describing the results of research that has been collected and analyzed [4]. 


\section{RESULT AND DISCUSSION}

Authority of administrator in suspension of payment is announcing decision of suspension of payment, preparing meetings, receiving and preparing bill of creditor list, preparing a settlement plan with debtors, preparing voting list and creating report of suspension of payment [5].

Based on article 226 of Law number 37 year 2004 concerning bankruptcy and suspension of payment, the administrator shall immediately announce the decision on temporary suspension of payment in the state gazette of the republic of Indonesia and at least in 2 two daily newspapers [6]. Appointed by supervisory judge and announcement shall also contain an invitation to be present at the hearing which constitutes the consent of the judge following the date, place and time of the hearing, the name of the Supervisory Judge and the name and address of the Administrator [7].

Declaration Number: 4/Pdt. Sus-PKPU/2017/PN. Niaga Sby has been decided in the consultative meeting of the commercial court judges at the Surabaya District Court on the Friday of March 17, 2017 and spoken on the day: Monday, Date: 20 March 2017 in a trial open to the public by the chief justice assembly accompanied by member judge assisted by substitute registrar attended by the attorney of the petitioners of suspension of payment and the power of attorney the respondents of suspension of payment and the power of attorney other creditor.

Judge of commercial court at Surabaya district court appointed by decision of judge of commercial court at Surabaya district court number: 4/Pdt.Sus-PKPU/2017/PN. Niaga Sby, dated March 20, 2017, stipulates the establishment of a commercial court supervisory judge at the Surabaya District Court Number: 4/Pdt. Sus-PKPU/2017/PN. Niaga Sby on Thursday, March 23, 2017, instructs the administrator team to announce the decision temporary suspension of payment number: 4/Pdt. Sus-PKPU/PN. Niaga Sby dated March 20, 2017 in two daily newspapers namely: a. Media Indonesia; b. Bali Post.

The administrators have announced the declaration of the constitutional court judge number: 4/Pdt. Sus PKPU/2017/PN. Niaga. Sby dated March 20, 2017 stipulated in the Establishment of Supervisory Judge Number: 4/Pdt. Sus - PKPU/2017/PN. Nus. Sby dated March 23, 2017 in 2 (two) daily newspapers namely: a. Media Indonesia on page $15, \mathrm{~b}$. Bali Post on page 3 and in the State News on the day: Friday, date: March 24, 2017.

Based on the declaration of the constitutional court judge number: 4/Pdt. Sus - PKPU/2017/PN. Niaga. Sby dated March 20th, 2017 stipulated in the establishment of supervisor's number: 4/Pdt. Sus - PKPU/2017/PN. Niaga. Sby dated March 23th, 2017, the administrators held meetings, among others: first creditor meeting, meetings with debtors, praverification meeting, creditor's billing and tax verification [8].

Until the deadline for the application of tax claims and charges of creditors on Friday, April 7th, 2017, creditors who register there are 4 (four) creditor namely: PT. Bank UOB Indonesia, PT. Catur Bangun Mandiri Perkasa, KPP Pratama
Bandung Selatan and Regional Revenue Board/Pasedahan Agung Badung Regency.

On Friday, April 7th, 2017, the administrator's team lists creditors and prepares meetings with the debtor in respect of property debt management [9]. On Saturday, April 8, 2017, the administrator team together with the debtor prepared a draft settlement plan. On Sunday, April 9, 2017, the administrator team received the draft settlement plan from PT. RR and JCT. The settlement plan is the heart of the suspension of payment. Based on the settlement plan agreed upon by the parties and ratified (homologasi) by the judge of the assembly at the meeting of the panel of judges after the end of suspension of payment. Voting is conducted to fulfill the formulation of Article 229 paragraph (1) and Article 281 paragraph (1) Law Number 37 Year 2004 concerning Bankruptcy and Suspension of Payment (UUK).

Under Article 239 paragraph (1) UUK, administrators shall report on the condition of debtor's property [10]. In addition to reporting the property of the debtor, the administrators also reports on the management process at each meeting set by the judge of the supervisor and judge of the assembly [11]. meetings set by the supervisory Judge and have been announced by the administrator are the first creditor meeting, the creditor billings and tax verification matching meeting, and the consultative assembly of the judge of the assembly [12].

Suspension of payment procedure begins with a suspension of payment application filed by the debtor or by a creditor [13]. The suspension of payment application filed by the debtor or by the creditors shall be granted by the court by issuing a declaration which contains temporary the suspension of payment for a maximum of 45 days and can be extended by issuing the deferred declaration on the fixed suspension of payment for a maximum of 270 days [14]. The suspension of payment verdict should appoint a supervising judge from a court judge and appoint one or more administrator who together with the debtor manage the debtor's property [15].

After the declaration of the panel judge on suspension of payment appointing the supervisory judge and appointing the administrator, the administrator immediately faces the supervisory judge to request the establishment of a supervisory judge to set a schedule for the implementation of the suspension of payment [16]. Armed with the establishment of a supervisory judge on the schedule for the implementation of the suspension of payment, the administrator announced the schedule of suspension of payment in the national media and the regional media as well as the state news [17]. The schedule of suspension of payment shall contain the schedule of the first creditor meeting, the deadline for registration of bills, the creditor's charges and tax verification [18]. At the latest on the 45th day of the decision of panel judge on the suspension of payment, the court hearing of the panel judge on the extension of suspension of payment from temporary suspension of payment to permanent suspension of payment shall be renewed at the latest 270 days after the issuance of the suspension of payment decision [19].

Application for suspension of payment of PT. RR and JCT in commercial court in Surabaya district court filed by pt. bank UOB Indonesia. Applicants for suspension of payment are: PT. 
$\mathrm{RR}$ as respondent I and JCT, as respondent II. The respondent I and respondent II besides having a loan to suspension of payment petitioner, also has a debt to other creditors namely PT. Mandiri perkasa Catur bangun, bearing the address at 35th Kebayoran Lama street, RT.008/RW.001 Sub-District of South Sukabumi, Kebon Jeruk District, West Jakarta

Declaration Number: 4/Pdt. Sus-PKPU/2017/PN. Niaga Sby has been decided by the Panel of Judges at the Surabaya District Court on Monday, 20 March 2017 in a trial open to the public by the Chief Panel of Judges assisted by substitute registrar attended by the attorney of the petitioners of suspension of payment and the power of the respondents of suspension of payment and the power of other creditor.

Supervisory judge of commercial court at Surabaya district court appointed by declaration panel of judges of commercial court at Surabaya District Court Number: 4/Pdt. SusPKPU/2017/PN. Niaga Sby, dated March 20, 2017, stipulates the establishment of a commercial court supervisory judge at the Surabaya district court number: 4/Pdt. Sus-PKPU/2017/PN. Niaga Sby on Thursday, March 23, 2017, instructs the management team to announce the declaration temporary suspension of payment number: 4/Pdt. Sus-PKPU/PN. Niaga Sby dated March 20, 2017 in 2 (two) daily newspapers namely: Media Indonesia and Bali Post.

Based on the declaration of the panel of judges number: 4/Pdt. Sus - PKPU/2017/PN. Niaga. Sby dated March 20, 2017 stipulated in the Supervisory Judge Establishment Number: 4/Pdt. Sus - PKPU/2017/PN. Niaga. Sby Date March 23, 2017, the Administrators held meetings, among others: First Creditor Meeting, Meetings with Debtors, Praverification Meeting and Creditor's Billing and Tax Verification.

On April 27, 2017, the Suspension of Payment Obligations (PKPU) Voting Meeting has been held. The Debtor submitted a request for extension of Suspension of payment for 90 days as outlined in the settlement plan. Against the petition for extension of suspension of payment, the separatist creditors of PT. Bank UOB Indonesia, which has $100 \%$ of the vote of separatist creditors, approved the extension of suspension of payment for 75 days. PT. Catur Bangun Mandiri Perkasa, a concurrent creditor who has $100 \%$ of the votes of the constituent creditor, approved the extension of suspension of payment for 75 days. Based on the approval of the separatist creditors and the concurrent creditor, the administrator through the supervisory judge, please to the honorable judges of the panel of judges in the commercial court hearing, permanent suspension of payment with extension suspension of payment for 75 days from the day, date: Wednesday, May 3th, 2017 until Monday, July 17th, 2017.

\section{CONCLUSIONS}

Authority of administrator in suspension of payment PT. RR and JCT is with the debtor's to manage debtor's assets and immediately reminds the debtor to submit a settlement plan. If the debtor's does not prepare a settlement plan, there should be bankrupt. The very important procedure of payment suspension in commercial court is to prepare a settlement plan.

\section{ACKNOWLEDGEMENT}

The author would like to thank all the parties who have helped and contributed in the writing of this article, both those who contribute in the form of funding and critical ideas. Hopefully this paper can be useful theoretically and practically for the addition and development of knowledge, especially in the field of legal science.

\section{REFERENCES}

[1] Decision of Commercial Court in Surabaya District Court No. $04 /$ Pdt.Sus-PKPU / 2017 / PN. Commerce Sby. March 20, 2017.

[2] Eriksson, P. and Kovalainen, A., Qualitative methods in business research: A practical guide to social research. Sage. 2015.

[3] Hancock, D. R. and Algozzine, B., Doing case study research: A practical guide for beginning researchers. Teachers College Press. 2016.

[4] Marzuki, P. M., Legal research. Kencana Prenada Media Group, Jakarta. 2005.

[5] J. Hoff, Indonesian Bankruptcy Law, PT. Tatanusa, Jakarta. 1999.

[6] Law of the Republic of Indonesia Number 37 Year 2004 concerning Bankruptcy and Suspension of Payment.

[7] Hadi, S. M., Bankruptcy Law: Principles, Norms, and Practices in Court, Prenada Media Group, Jakarta. 2008.

[8] Wedoff, E. R., Major consumer bankruptcy effects of the 2005 reform legislation. UNIFORM COMMERCIAL CODE LAW JOURNAL, 38(2). 2005.

[9] Mincu, C., Innovative Operations Strategies for the Credit and Debt Collection Teams of the Non-financial Creditors. 1. Back to Business from Competition Policy Point of View 9. 2012.

[10] Altman, E. I. and Hotchkiss, E., Corporate financial distress and bankruptcy: Predict and avoid bankruptcy, analyze and invest in distressed debt (Vol. 289). John Wiley \& Sons. 2010.

[11] Sobol, N. L., Charging the Poor: Criminal Justice Debt and Modern-Day Debtors' Prisons. Md. L. Rev., 75. 2015.

[12] Hong-Barco, P. C., How the Fair Credit Reporting Act Fails to Protect: The Case of IRS Tax Liens on Consumer Credit Reports. Pitt. Tax Rev., 3. 2005.

[13] Couwenberg, O. and De Jong, A., Costs and recovery rates in the Dutch liquidation-based bankruptcy system. European Journal of Law and Economics, 26(2). 2008.

[14] Farn, J., Bankruptcy and Bankruptcy Procedure in the United Arab Emirates. In Global Insolvency and Bankruptcy Practice for Sustainable Economic Development. Palgrave Macmillan, London. 2016.

[15] Steele, S., Appointing and Remunerating Insolvency Practitioners in Japan: The Roles of Japanese Courts. International Insolvency Review, 26(1). 2017.

[16] Manring, T. A., Debt restructuring in Indonesia. Sing. J. Int'l \& Comp. L., 3. 1999.

[17] Hüpkes, E. H., Learning lessons and implementing a new approach to bank insolvency resolution in Switzerland. In Who Pays for Bank Insolvency? Palgrave Macmillan, London. 2004.

[18] Hildebrand III, H. E., Impact of the Bankruptcy Abuse Prevention and Consumer Protection Act of 2005 on Chapter 13 Trustees. Am. Bankr. LJ, 79. 2005.

[19] Greenbaum, A. F., Administrative and Interim Suspensions in the Lawyer Regulatory Process-A Preliminary Inquiry. Akron L. Rev., 47. 2014. 